
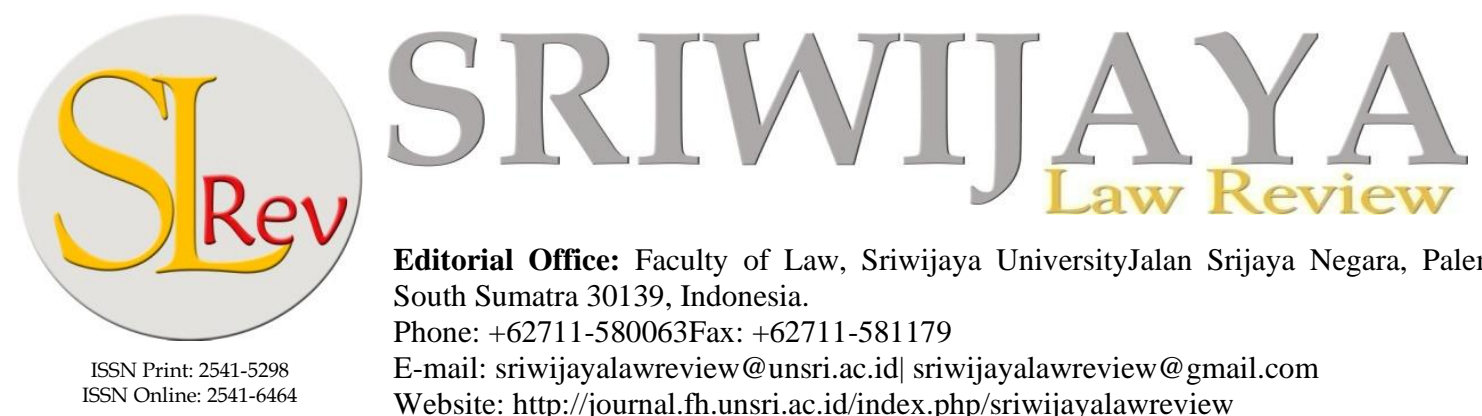

Editorial Office: Faculty of Law, Sriwijaya UniversityJalan Srijaya Negara, Palembang, South Sumatra 30139, Indonesia. Phone: +62711-580063Fax: +62711-581179

E-mail: sriwijayalawreview@unsri.ac.id| sriwijayalawreview@gmail.com

Website: http://journal.fh.unsri.ac.id/index.php/sriwijayalawreview

\title{
Public Policy Defense and the Arbitrability of Competition Disputes Under the Philippine Arbitration Regime
}

\author{
James Gregory Alcaraz Villasis ${ }^{\mathrm{a}}$
}

a College of Law, Polytechnic University of the Philippines, Philippines. Email: jgavillasis@pup.edu.ph

\begin{tabular}{|c|c|}
\hline Article & \multirow{2}{*}{$\begin{array}{l}\text { Abstract } \\
\text { The arbitrability of anti-competition disputes in the Philippines remains }\end{array}$} \\
\hline Keywords: & \\
\hline $\begin{array}{l}\text { Public Policy Defense; } \\
\text { Arbitrability; Philippine }\end{array}$ & $\begin{array}{l}\text { to be tested. It is since the Philippine Competition Act is relatively at its } \\
\text { infancy, and cases are yet to be brought before the courts. This area en- }\end{array}$ \\
\hline Domestic Arbitration; & tails much complexity considering that competition disputes are by na- \\
\hline Philippine Competition & ture imbued with public policy concerns, a mandatory exception for arbi- \\
\hline $\begin{array}{ll}\text { Law; } & \text { Competition } \\
\text { Disputes. } & \end{array}$ & tration. This paper aims to examine the arbitrability of competition dis- \\
\hline & $\begin{array}{l}\text { an examination of cases and literature both in the Philippines and abroad, } \\
\text { the paper argues that the Philippines may consider the US and French }\end{array}$ \\
\hline Artikel History & positions as to the arbitrability of competition disputes despite the \\
\hline $\begin{array}{l}\text { Received: May 24, 2019; } \\
\text { Reviewed: Jan 21, 2020; }\end{array}$ & presence of various public policy concerns. The public policy issues \\
\hline Accepted: Jan 30, 2020; & $\begin{array}{l}\text { should only be taken into consideration when an arbitral award is brought } \\
\text { before judicial bodies for recognition and enforcement and should not bar }\end{array}$ \\
\hline Pubinsned: Jan 31,2020 . & $\begin{array}{l}\text { domestic arbitral bodies from taking cognizance of these disputes. It is to } \\
\text { accommodate the state policy regarding alternative means of settling }\end{array}$ \\
\hline & \\
\hline $\begin{array}{l}\text { 10.28946/slrev.Vol4.Iss2. } \\
\text { 294.pp79-90 }\end{array}$ & $\begin{array}{l}\text { Whenever an award is granted, the same will be subject to court's } \\
\text { intervention for recognition with due respect to the public policy } \\
\text { concerns. In so doing, arbitration is being promoted without sacrificing } \\
\text { the competition law policy of the Philippines. }\end{array}$ \\
\hline & \\
\hline
\end{tabular}

\section{INTRODUCTION}

On 22 July 2015, the enactment of Republic Act Number 10667, otherwise known as the Philippine Competition Act (hereinafter PCA), made headlines. ${ }^{1}$ The public consumers positively received such news because a law, which offers the hope for the protection of the welfare of the general public against anti-competitive practices of business considered as 1 ABS-CBNnews.com, 'PNoy Signs PH Competition Act', 2015 < https://news.abs-
cbn.com/business/07/21/15/pnoy-signs-ph-competition-act> [accessed 21 February 2019]. 
disadvantageous to the consumers, was realized after being stalled in Congress for almost twenty years. ${ }^{2}$

Considering that the PCA was brought to fruition roughly for three years now, it is relatively in its infancy stage. Much of its provisions are yet to be put to the test in actual disputes wherein the competing interests of the public stakeholders and private businesses are resolved. Nonetheless, the anticipation regarding the effectiveness of the law in meeting its declared policies remains to be high.

Although in other jurisdictions, mostly in the western countries, antitrust laws are rich as may be seen in their respective bodies of case laws, Philippine competition law seemingly tread a path where there is a probability of borrowing judicial and administrative practices observed in these (other) jurisdictions. For instance, the legal aspect of the arbitrability of competition disputes is a rich turf subject of heated legal debates in recent decades.

In the Philippines, arbitration is aimed towards its utilization for speedy administration of justice and as an alternative to judicial recourses, thereby preventing any undue burden to the court's dockets. ${ }^{3}$ This policy is even confirmed as to the manner how Philippine Courts view arbitration. ${ }^{4}$ To date, there is no clear path in the Philippine jurisdiction in settling disputes involving competition law through arbitration.

A present legal framework involving arbitration as a legal tool is well-entrenched in the Philippine legal system. Notwithstanding this, the question as to the propriety of using arbitration as a legal tool in resolving these kinds of disputes remains to be suspect, especially that competition disputes are by nature entangled with public policy, a clear mandatory exception as to the arbitrability of particular subject matters.

The central problem then is what should be the proper position for the Philippines if a competition dispute involving the use of arbitration as a legal tool arises. This paper attempts to answer this question by mainly attacking the arbitrability of competition disputes under the existing legal framework concerning domestic arbitration. In so doing, the first part will discuss the Philippine arbitration system and the competition law. The second part will look into the positions in other jurisdictions concerning such arbitrability. The third part will provide for the synthesis of the first and second parts arguing for the arbitrability of competition disputes in the Philippines, thereby effectively touching on the issue of public policy defense. The fourth and last part will attempt to offer a view on the proper position of the Philippines concerning the arbitrability of competition disputes.

However, this examination is limited only to domestic arbitration and will not touch aspects falling under international commercial arbitration. Further, this paper will not deal with great particularity on the competition law system in the Philippines. Instead, a brief account of this law will be merely provided. The analysis of this paper will be focused more on the aspect of public policy exceptions to arbitration vis-à-vis competition disputes.

2 Kristine Angeli Sabillo, 'Aquino Signs PH Competition Act, Amendment to Cabotage Law', Inquirer.Net, 2012 <https://business.inquirer.net/195649/aquino-signs-ph-competition-act>.

3 Republic Act Number 9285 on Alternative Dispute Resolution Act of 2004, 2004.

4 Department of Environment and Natural Resources v. United Planners Consultants, Inc., G.R. No. 212081 (2015); Department of Foreign Affairs v. BCA Corporation International \& Ad Hoc Arbitral Tribunal, G.R. No. 210858 (2016). 


\section{ANALYSIS AND DISCUSSION}

\section{The concept of arbitrability under the regime of domestic arbitration in the Philippines}

Domestic arbitration refers to arbitration, which is not international. ${ }^{5}$ It means that when both parties have their principal place of business within the Philippines, then the arbitration is considered to be domestic by nature. ${ }^{6}$ The rules on domestic arbitration in the Philippines are primarily provided under Republic Act Number 876 or the Arbitration Law of 1953. It outlines the process of crafting arbitration agreements between parties concerned, as well as the appointment of arbitrators and the rules in arbitrating civil cases. In 2004, however, Arbitration Law was amended by the passage of Republic Act Number 9285, otherwise known as the Alternative Dispute Resolution Act of 2004.

The ADR Law is explicit as to its amendatory effect to the previous Arbitration Law. ${ }^{7}$ This law, however, further authorized the crafting of two subsequent issuances respecting arbitration in general. The first is the Implementing Rules and Regulations of the Alternative Dispute Resolution Act formulated by the Executive Department through the Department of Justice. The second is the A.M. No. 07-11-08-SC or the Special Rules of Court on Alternative Dispute Resolution promulgated by the Philippine Supreme Court.

Presently, as may be gleaned from the provisions of the Arbitration Law, the ADR Law, the Arbitration IRR and the Special Rules on Arbitration, the procedure for domestic arbitration in the Philippines may be outlined, at least for the purpose of this paper, into "three phases": first, submission of the dispute to arbitration; ${ }^{8}$ second, the conduct of the arbitral proceedings and the rendering of the arbitral awards (Article 5.20); ${ }^{9}$ and third, the confirmation, correction, or vacation of the award and review (Article 5.20 (a)). ${ }^{10}$

Under the first phase, parties refer the dispute to arbitration if a prior arbitration agreement was validly entered between them, or if there is no such agreement, by demand of one of the parties (Article 5.20 (d)). ${ }^{11}$ Here, the dispute may either be pending before the court or not. In both cases, notwithstanding, the party invoking the conduct of arbitration proceedings may still validly do so. Under the first instance, where a prior agreement was in place, the arbitration may be initiated depending on whether it will be heard through an institutional arbitration or an ad hoc (Article 5.20 (i and ii)). ${ }^{12}$ Meanwhile, under the second instance, where there was no pre-existing arbitration agreement, the proceeding is commenced upon the agreement of the other party to whom the demand was made to submit

\footnotetext{
Republic Act Number 9285 on Alternative Dispute Resolution Act of 2004.

UNCITRAL Model Law of International Commercial Arbitration (https://www.uncitral.org/pdf/english/texts/arbitration/ml-arb/07-86998_Ebook.pdf).

Republic Act Number 9285 on Alternative Dispute Resolution Act of 2004.

8 Department of Justice, Department of Justice Circular Number 098 on the Implementing Rules and Regulations of the Alternative Dispute Resolution Act of 2004.

9 Department of Justice.

10 Department of Justice.

11 Department of Justice.

12 Department of Justice.
} 
the case to arbitration (Article 5.20 (d)). ${ }^{13}$ Nevertheless, in both instances, the selection of the arbitrators will follow.

Under the second phase, the arbitration proceedings will be conducted. If it is an institutional arbitration, the rules of the institution duly selected by parties to undertake the arbitration will be observed during the conduct of the same while in ad hoc arbitration, the written procedure formulated by the selected arbitrators with the assent of the parties will govern (Article 5.23 (a)). ${ }^{14}$ Thirty days after the closing of the hearing, an award will be rendered by the arbitrator/s based on their majority votes, unless otherwise agreed upon by the parties (Article 5.29 (a and b))..$^{15}$

The third phase of the arbitration proceeding refers to the judicial action concerning the arbitral award. A party may file a petition to the court within thirty days from the receipt of the arbitral award for the confirmation or vacating of the said award. ${ }^{16}$

From the preceding phases of domestic arbitration, the concept of arbitrability becomes relevant, firstly, at the stage of referral of the dispute to arbitration. In this phase, a party may oppose the referral dispute to an arbitral tribunal or arbitrators on the ground that the same is removed outside of the jurisdiction of tribunal. Nevertheless, it is only the tribunal concerned has the authority to rule on its proper jurisdictional matters, given that the Special $A D R$ Rules explicitly recognize the principle of competence. Consequently, court intervention at this stage is not proper and is considered as an undue arrogation of its judicial power (Rule 2.4). ${ }^{17}$ The second stage, where the concept of arbitrability comes into place is during the recognition phase. Here, Courts are called upon to recognize an arbitral award. However, such may be opposed on the ground that the subject-matter of the dispute is not arbitrable under Philippine law (Rule 2.4 (b.i). ${ }^{18}$

Notwithstanding the discussion on the relevance of arbitrability, the 1953 Arbitration Law is silent about this concept. However, what may be inferred from its provisions is that all disputes except those falling under the authority of the CIR are arbitrable so long as the agreement is valid under the law on contracts and that the parties are capacitated to give consent to such an agreement. ${ }^{19}$ This concept has been expanded by the Special ADR Rules when a party may oppose the recognition or even initiate the vacating of an arbitral award when it is shown that the subject matter of the award is beyond the tribunal's authority or if the same runs contrary to public policy. ${ }^{20}$

Consequently, a matter is arbitrable if it satisfies the objective and the subjective elements. First, objective elements refer to the validity of the arbitration agreement itself with particular reference to the contractual requirements under the New Civil Code of the Philippines (1949). Second, subjective elements refer to the issues surrounding the dispute

13 Department of Justice.

14 Department of Justice.

15 Department of Justice.

16 Republic of the Philippines Supreme Court, Administrative Matter Number 07-11-08-SC on Special Rules of Court on Alternative Dispute Resolution.

17 Republic of the Philippines Supreme Court.

18 Republic of the Philippines Supreme Court.

19 Republic Act Number 876 on The Arbitration Law.

20 Special ADR Rules, supra note 16 at Rule 19.10. 
itself. It may refer to the propriety of the subject matter to arbitration or the concept of public policy.

\section{The Public Policy Defense in Philippine Domestic Arbitration}

The anterior part discussed the phases of arbitration and the concept of arbitrability under the domestic arbitration regime in the Philippines. Public policy has been introduced as one of the additions to the expanded definition of arbitrability as this concept evolved from the 1953 Arbitration Law to the 2004 Special ADR Act. An examination of the arbitrability and public policy issue would reveal an observation that these two concepts are intertwined since the subject-matter coverage of arbitration has the public policy issue as an integral part of it. Take, for instance, the subject matter such as labor disputes, criminal activity, and civil status of a person, which are prohibited from being objects of arbitration. ${ }^{21}$ These are so prohibited, considering that the arbitration of these matters will generally violate public policy. ${ }^{22}$

Although it is true that unlike the issue of arbitrability of a particular dispute, a public policy only comes into play when the award has been rendered that a party to the dispute either moves for the recognition or non-recognition of the said award. The public policy defense is a contentious issue given that the present Philippine legal system seemingly leaves a void with respect to the concrete concept of public policy, thereby causing unpredictability as to the outcome of an arbitration proceeding in general. ${ }^{23}$ What remains, however, is the fact that when there is a determination that the award counters the settled public policy in the Philippines, the court is mandatorily commanded by law to set aside such an award (Rule 19.10). ${ }^{24}$

Thus, public policy may be considered as a defense against the recognition and enforcement of an arbitral award. In international commercial arbitration, unlike in domestic, this has been narrowly defined concerning its qualification as a mandatory rule. According to Gaillard and Savage, ${ }^{25}$ public policy may only be interposed as a valid ground to vacate an award if it violates the fundamental rule on due process. Such a view is rather myopic as it treats public policy only within the aspect of the conduct of the arbitration proceeding and not on the subject-matter issue. It is short of saying that public policy is confined within the procedural aspect of arbitration to which the court may only look. The reason behind this perhaps lies in the fact that the identification of a robust public policy defense in international commercial arbitration is more complicated than on its domestic counterpart. It is since more than one jurisdiction is involved in the former, while only one is to be considered in the latter. Consequently, the identification of the public policy concept in

21 Republic Act Number 9285 on Alternative Dispute Resolution Act of 2004.

22 Serap Zuvin and Mehmet Ali Akgun, 'Turkey: Public Policy Defence and Arbitration in International Commercial Law', Serapzuvin Law Offices, 2015 <turkey: Public Policy Defence and Arbitration in International Commercial Law>.

23 Hailin Bao \& Tianyo Zhan Haoqian Chen, 'Piercing the Veil of Public Policy in the Recognition and Enforcement of Foreign-Related Awards in China', Beijing Law Review, 7.1 (2016), 23-32.

24 Republic of the Philippines Supreme Court.

25 Emmanuel Gaillard and John Savages (eds), 'Fouchard Gaillard Goldman on International Commercial Arbitration', Uniform Law Review, 5 (1999), 632-853. 
the regime of domestic arbitration in the Philippines only entails an examination of the state policies being observed within the Philippine legal system.

It is worth noting that Philippine laws have repeatedly mentioned the principle of public policy, albeit lack of thorough clarifications on the matter. The Supreme Court in Emeterio Cui v. Arellano University ${ }^{26}$ held that four factors are required to be considered in determining the public policy of a state, thus:

“(i)n determining a public policy of the state, courts are limited to a consideration of the Constitution, the judicial decisions, the statutes, and the practice of government officer". (Emphasis supplied).

The court even proceeded that the public welfare should be the primordial consideration in recognizing an act as against public policy. ${ }^{27}$ As a consequence, the Supreme Court has, in a way, declared public policy as intertwined with the notion of public welfare.

Otherwise stated, public policy concerning arbitration may be assumed to mean that an award may be vacated if it militates against the settled "fundamental principles of justice, honesty, and fairness". ${ }^{28}$ Moreover, if the dispute subject of arbitration includes matters which will affect the public welfare, then the court will be justified in vacating the award rendered in such a proceeding based on a public policy defense.

\section{The Philippine Competition Law and The Arbitrability Of Competition Disputes vis-à- vis Public Policy Concerns}

This part briefly discusses the competition law regime in the Philippines as well as the disputes which may arise from the same law. After possible sources of disputes have been identified, their arbitrability will be further tackled with particular reference on the public policy concerns. As established in the earlier portions of this paper, the Republic Act Number 10667 or the Philippine Competition Act of 2015 is the body of law which envisions carrying out sound state policies of enhancement of economic efficiency, promotion of free and fair competition, and prevention of economic concentration in trade and industry. ${ }^{29}$ In so doing, this law prevents the following business practices, which are deemed to be anti-competitive: anti-competitive agreements (Section 14), ${ }^{30}$ abuse of dominant positions (Section 15), ${ }^{31}$ and anti-competitive mergers and acquisitions (Section 16). ${ }^{32}$ To ensure the strict adherence to these provisions, the Philippine Competition Commission (hereinafter PCC) was created, which has the original and primary jurisdiction to enforce and regulate the anti-competitive acts of businesses or even related issues (Section 12). ${ }^{33}$

From the preceding, it may be inferred that a dispute concerning competition law may primarily arise between states itself through the PCC on one side and the private businesses

26 Emeterio Cui v. Arellano University, G.R. No. L-15127 (1961).

27 Ritter vs. Mutual Life Ins. Co., 169 U.S. 139; Heding vs. Gallaghere 64 L.R.A. 811; Veazy vs. Allen, 173 N.Y. 359.

28 Zuvin and Mehmet Ali Akgun.

29 Republic Act Number 10667 on the Philippine Competition Act.

30 Republic Act Number 10667 on the Philippine Competition Act.

31 Republic Act Number 10667 on the Philippine Competition Act.

32 Republic Act Number 10667 on the Philippine Competition Act.

33 Republic Act Number 10667 on the Philippine Competition Act. 
on the other. Here, the enforcement and regulatory power of the PCC is being exercised in order to protect and promote the declared policies. However, private parties may also be involved in competition disputes without the involvement of the state. It is especially true when the dispute purely involves a contractual agreement between private entities, which has an element of anti-competitive issues. However, any anti-competitive violations amounting to tortious infractions between these private entities may be considered as private and may be arbitrated if the arbitration contract covers it. If the agreement to arbitrate does not cover the same, it may still be subjected to this mode of alternative dispute resolution if the parties enter into a contract after the occurrence of the fact. ${ }^{34}$

The delineation of the two possible areas of disputes involving competition law is relevant when using arbitration as a tool in settling such disputes. According to the Organisation for Economic Co-operation and Development (hereinafter OECD), arbitration as a tool may be used to settle competition disputes under two circumstances. First, purely contractual under which an individual invokes the use of arbitration in resolving private disputes. Second, the enforcement of competition law by assigned authorities. ${ }^{35}$ In a nutshell, two disputes may arise from competition law: private and public disputes.

The confusion now becomes more apparent than ever as to the propriety of using arbitration as a tool in dispute settlement. At the outset, it may be argued that arbitration cannot be used in resolving public competition disputes, i.e., the state through the Philippine Competition Commission against a private entity. At the same time, the contrary is true when the dispute involves purely private interests. Then again, the fact cannot be discounted that competition law disputes are by nature embedded with public policy concerns as textualized in the PCA. Consequently, a counter-argument that all competition disputes can never be arbitrated based on a sound policy of the state. On this note, in reconciling these diametrically opposed arguments, it is but proper to look into other jurisdictions as to how they have settled the issue of arbitrability of competition disputes considering that actual case is yet to be brought before the Philippine Supreme Court and that the competition law under this jurisdiction is still on its relative infancy stage.

The United States case laws are the authority on this matter. The evolution of the position of the United States may be traced back to the 1968 case of American Safety Equipment Corporation v. J.P. Maguire \& Co $^{36}$ (hereinafter American Safety) where the court explicitly declared that competition disputes could not be a valid subject of arbitration, hence not arbitrable. The reasoning of the court, in this case, is founded on the issue that the resolution of competition law disputes cannot be granted to the decision of an arbitral tribunal given the fact that it is so broad to the extent that the interest of the public is affected thereby causing great "economic damage." 37 Here, it should be noted that an arbitration agreement between two private entities is entered into force. No agency of the

\footnotetext{
34 Miriam Driessen and Reilly, 'Private Damages in EU Competition Law and Arbitration: A Changing Landscape', Arbitration International, 31.4 (2015), 576.

35 'OECD Hearings Arbitration and Competition', Organisation for Economic Co-Operation and Development, $2010<\mathrm{https}$ //www.oecd.org/daf/competition/abuse/49294392.pdf>.

36 American Safety Equipment Corporation v. J.P. Maguire \& Co., 391 F.2d 821 (1968).

37 American Safety Equipment Corporation v. J.P. Maguire \& Co., 391 F.2d 821 (1968).
} 
Government was called upon to enforce anti-competition regulations. Nonetheless, this ratiocination is in line with the public policy defense as an exception to the arbitrability of a competition dispute.

For decades, the US courts' holding in the American Safety was consistently upheld but was later on revisited and abandoned in the 1985 case of Mitsubishi Motors Corp. v. Soler Chrysler-Plymouth Inc. ${ }^{38}$ (hereinafter Mitsubishi Motors) where the US Court ruled that arbitration may be used as a tool in resolving competition disputes. The central thesis in the American Safety that the courts and not the arbitrators should have the jurisdiction over the dispute was challenged in Mitsubishi Motors when it observed that "arbitration tribunals are not yet tested and that cannot be assumed to be incapable of handling the matter". ${ }^{39}$ As such, as succinctly observed by Werlauff, the Mitsubishi Motors holding imply that a competition dispute is not per se non-arbitrable but is principally arbitrable, but the arbitral award may be contrary to public policy. ${ }^{40}$

It held when the Mitsubishi Motors laid down the "second look doctrine," which grants to the court the power to look into the arbitral award and test it whether it violates the sound public policy. ${ }^{41}$ Thus, it may well be argued that the Mitsubishi Motors ruling was a middle path wherein the court's competence to look into the arbitral award in consideration of public policy concerns is a compromise as to the previous non-arbitrable position of competition disputes in the US.

Other jurisdictions, especially those who are members of the European Union, trod the same path as in the US' Mitsubishi Motors. France's position on the arbitrability of competition disputes is one of the most akin to the US position. In French jurisdiction, the issue of the arbitrability of such issues on the ground of public policy issue may be raised during the enforcement of the award by judicial action, ${ }^{42}$ a position which is similar to the Mistubishi's second look doctrine. However, as a slight departure from this doctrine, the French Court held in SNF SAS v. Cytec Industries $B V^{43}$ that this may be confirmed by the court unless there is a gross violation of the competition law.

The United Kingdom's position, on the other hand, is more progressive, considering that the arbitrability of competition disputes was explicitly recognized in all phases of the arbitration proceedings. It means that the English notion of arbitrability is much broader as compared to other jurisdictions as this has included the public policy defense is relevant not only during the judicial review but also during the referral of the dispute to arbitration.

38 Mitsubishi Motors Corp. v. Soler Chrysler-Plymouth Inc., 723 F.2d 155 (1983), cert. granted, 105 S. Ct. 291 (1984).

39 Mitsubishi Motors Corp. v. Soler Chrysler-Plymouth Inc., 723 F.2d 155 (1983), Cert. Granted, 105 S. Ct. 291 (1984).

40 Erik Werlauff, 'Private Arbitration of Incidental Public Law Issues', European Business Law Review, 20.4 (2009), 495-656.

41 Gordon Blanke and Renato Nazzini, 'Arbitration and ADR of Global Competition Disputes: Taking Stock', Global Competition Law Review, 1.3 (2008), 1-15.

42 Karim Y Youssef, The Death of Inarbitrability, First Arbitrability: International and Comparative Perspectives, ed. by Loukas Mistelis and Stavros Brekoulakis (Kluwer Law International, 2009).

43 Mitsubishi Motors Corp. v. Soler Chrysler-Plymouth Inc., 723 F.2d 155 (1983), Cert. Granted, 105 S. Ct. 291 (1984). 
However, as confirmed in ET Plus SA\& Ors v. Welter \& Ors ${ }^{44}$ (hereinafter ET Plus), this should not be taken liberally as the propriety of the use of arbitration should be read to have been explicit on the arbitration clause between the parties.

It is clear from the foregoing examination on varying positions on the arbitrability of competition disputes in France, US, and UK that its arbitrability is recognized but at different phases. However, another qualification was inserted by the OECD ${ }^{45}$ in 2010 when it confirmed the arbitrability of competition disputes but concerning the domestic competition law of the jurisdiction concerned, and the arbitrator will not impair the jurisdiction of the enforcement agency. ${ }^{46}$ This position by the $\mathrm{OECD}^{47}$ may only be applied in instances wherein the subject of the arbitration is a competition dispute which is public (as previously delineated from its private counterpart).

\section{Arbitrating Competition Disputes: Position For the Philippines}

In evaluating whether competition disputes in the Philippines may be arbitrated despite public policy concerns, there is a need to re-examine first the competing policies on arbitration as opposed to competition issues. As established, the domestic policy on arbitration is for the use of arbitration in achieving a "speedy and impartial justice". ${ }^{48}$ It means that the Philippines promotes the use of arbitration in resolving a dispute as an alternative to judicial recourse. A competing policy on competition law, on the other hand, is geared towards economic efficiency by curbing anti-competitive practices. ${ }^{49}$ The primordial question now is to which policy should the balance be tilted?

Review of positions of other jurisdictions concerning the matter yields an observation that the future of competition disputes is towards the recognition of its arbitrability, even if there is an existence of public policy concerns. However, among these positions, the US position is most worthy of consideration. The Mitsubishi Motors ${ }^{50}$ is explicit that the fear of the capacity of arbitrators to settle competition disputes is unfounded since this has not been proven through hard cases. Nonetheless, this position does not merit much confidence in the Philippine system on domestic arbitration because the said case was decided in light of international commercial arbitration, a species of arbitration which is different from the domestic one in various respects. A revisiting of the preceding case of America Safety (1968) then is attractive since it recounts the fact that competition disputes are by nature so

44 ET Plus SA\& Ors v. Welter \& Ors EWHC 2115 (2005).

45 Although OECD's comments and positions do not hold normative value, the Philippine Supreme Court has yielded to these with potent effect. In various cases, the said court has cited OECD positions in settling issues concerning arbitration. See Heirs of Gamboa v. Finance Secretary Teves, et al., G. R. No. 176579, 9 October 2012 [Online]. Available https://lawphil.net/judjuris/juri2012/oct2012/gr_176579_2012.html\#rnt156v (retrieved: January 21, 2020).

46 American Safety Equipment Corporation v. J.P. Maguire \& Co., 391 F.2d 821 (1968).

${ }^{47}$ Notes that the Philippine Supreme Court gives OECD's position the stimulating effect. Although these do not form part of the domestic laws, they are consulted by the courts when it is confronted with different issues, especially those falling within the expertise of the organization.

48 Republic Act Number 9285 on Alternative Dispute Resolution Act of 2004.

49 Republic Act Number 10667 on the Philippine Competition Act.

50 Mitsubishi Motors Corp. v. Soler Chrysler-Plymouth Inc., 723 F.2d 155 (1983), Cert. Granted, 105 S. Ct. 291 (1984). 
encompassing as to include the interest of the public. Thus, the propriety of it being subject to arbitration is suspect.

In challenging the US Court's holding in American Safety, ${ }^{51}$ there is a need to qualify the concept of arbitrability in the Philippines again. As discussed, arbitrability in the domestic sphere merely deals with: first, the subject matter issue; and second, the validity of the agreement. Public policy concern, following a narrower interpretation of the term, is removed outside of the concept of arbitrability. As previously established, public policy defense may only be invoked at the last stage of domestic arbitration, where the recognition of the award is being sought. Thus, a strict reading of the subject-matter exceptions, as well as the contractual validity of arbitration clause, will give a conclusion that competition disputes may well be subject to arbitration, a position which is not explicitly prohibited by the Philippine Competition Act.

However, the framework by the French jurisdiction is equally attractive for the Philippines to consider where the court has the jurisdiction to look into the award and to test it whether it violates a settled policy. But the award may not be recognized on "flagrant" violation of the competition law. Otherwise stated, this position merely considers flagrant violations of competition laws to include public policy issues. This is a middle ground giving equal importance to the Philippines' declared policies on the use of arbitration and enforcing competition laws. However, the problem in this is in determining what should be considered as flagrant and what is not. ${ }^{52}$

\section{CONCLUSION}

This paper examined the position which the Philippines may take in arbitrating Philippine competition disputes under its domestic arbitration system, taking into account the practices in other jurisdictions where the matter has already been tested. It has argued that the Philippines may consider the US and French positions as to the arbitrability of such issues despite the presence of various public policy concerns. It has settled the notion of arbitrability as to be confined only within two bounds: first, the contractual validity of an arbitration agreement as stipulated under the 1953 Arbitration Law and was further confirmed in the 2004 ADR Act; and second, the subject-matter exceptions. The public policy issues should only be taken into consideration when an arbitral award is brought before judicial bodies for recognition and enforcement.

Admittedly, competition disputes are by nature imbued with public concerns, thereby elevating these into public policy exceptions. However, this should not be solely considered in striking all competition disputes as to be non-arbitrable, considering that the Philippines has an equally important policy in the promotion of the use of arbitration in resolving disputes.

Thus, the proper position for the Philippines is to consider competition disputes, whether private or public, as a proper subject of domestic arbitration. It is to accommodate the state policy regarding alternative means of settling disputes such as arbitration in

51 American Safety Equipment Corporation v. J.P. Maguire \& Co., 391 F.2d 821 (1968).

52 Yekaterina Kolmogorova, 'Arbitrability of Competition Disputes: Positions of England, France and Kazakhstan', Central European University, 2011 <www.etd.ceu.hu/2011/kolmogorova _yekaterina.pdf>. 
rendering speedy administration of justice. Whenever an award is granted, the same will be subject to the court's intervention for recognition with due respect to the public policy concerns. In so doing, arbitration is being promoted without sacrificing the competition law policy of the Philippines.

However, this position finds more weight only in the domestic arbitration system in the Philippines and not on the international commercial arbitration considering that the analysis of the public policy concerns surrounding these types of disputes is much more complicated in the latter system than in the former. Hence, for future discussions, it is recommended that a further examination be done as to the proper position of the Philippines whenever competition disputes containing foreign elements are involved.

\section{REFERENCES}

ABS-CBNnews.com, 'PNoy Signs PH Competition Act', $2015<$ https://news.abscbn.com/business/07/21/15/pnoy-signs-ph-competition-act> [accessed 21 February 2019]

American Safety Equipment Corporation v. J.P. Maguire \& Co., 391 F.2d 821 (1968)

Department of Environment and Natural Resources v. United Planners Consultants, Inc., G.R. No. 212081 (2015); Department of Foreign Affairs v. BCA Corporation International \& Ad Hoc Arbitral Tribunal, G.R. No. 210858 (2016)

Department of Justice, Department of Justice Circular Number 098 on the Implementing Rules and Regulations of the Alternative Dispute Resolution Act of 2004

Driessen, Miriam, and Reilly, 'Private Damages in EU Competition Law and Arbitration: A Changing Landscape', Arbitration International, 31.4 (2015), 576

Emeterio Cui v. Arellano University, G.R. No. L-15127 (1961)

ET Plus SA\& Ors v. Welter \& Ors EWHC 2115 (2005)

Gaillard, Emmanuel, and John Savages (eds), 'Fouchard Gaillard Goldman on International Commercial Arbitration', Uniform Law Review, 5 (1999), 632-853

Haoqian Chen, Hailin Bao \& Tianyo Zhan, 'Piercing the Veil of Public Policy in the Recognition and Enforcement of Foreign-Related Awards in China', Beijing Law Review, 7.1 (2016), 23-32

Kolmogorova, Yekaterina, 'Arbitrability of Competition Disputes: Positions of England, France and Kazakhstan', Central European University, 2011 <www.etd.ceu.hu/2011/kolmogorova_yekaterina.pdf>

Mitsubishi Motors Corp. v. Soler Chrysler-Plymouth Inc., 723 F.2d 155 (1983), cert. granted, 105 S. Ct. 291 (1984)

Nazzini, Gordon Blanke and Renato, 'Arbitration and ADR of Global Competition Disputes: Taking Stock', Global Competition Law Review, 1.3 (2008), 1-15

'OECD Hearings Arbitration and Competition', Organisation for Economic Co-Operation and Development, 2010 <https://www.oecd.org/daf/competition/abuse/49294392.pdf>

Republic Act Number 10667 on the Philippine Competition Act

Republic Act Number 876 on The Arbitration Law 
Republic Act Number 9285 on Alternative Dispute Resolution Act of 2004, 2004

Republic of the Philippines Supreme Court, Administrative Matter Number 07-11-08-SC on Special Rules of Court on Alternative Dispute Resolution

Ritter vs. Mutual Life Ins. Co., 169 U.S. 139; Heding vs. Gallaghere 64 L.R.A. 811; Veazy vs. Allen, 173 N.Y. 359

Sabillo, Kristine Angeli, 'Aquino Signs PH Competition Act, Amendment to Cabotage Law', Inquirer.Net, 2012 <https://business.inquirer.net/195649/aquino-signs-phcompetition-act>

UNCITRAL Model Law of International Commercial Arbitration (https://www.uncitral.org/pdf/english/texts/arbitration/ml-arb/07-86998_Ebook.pdf)

Werlauff, Erik, 'Private Arbitration of Incidental Public Law Issues', European Business Law Review, 20.4 (2009), 495-656

Youssef, Karim Y, The Death of Inarbitrability, First Arbitrability: International and Comparative Perspectives, ed. by Loukas Mistelis and Stavros Brekoulakis (Kluwer Law International, 2009)

Zuvin, Serap, and Mehmet Ali Akgun, 'Turkey: Public Policy Defence and Arbitration in International Commercial Law', Serapzuvin Law Offices, 2015 <turkey: Public Policy Defence and Arbitration in International Commercial Law> 